九州大学学術情報リポジトリ

Kyushu University Institutional Repository

\title{
Chemical Studies On Canned Meats
}

Okuda, Yuzuru

Biochemical Laboratory of the Department of Agriculuture, Kyushu Imperial University

Yamafuji, Kazuo

Food Chemistry Laboratory of the Department of Agriculuture, Kyushu Imperial University

Katai, Kitaro

Biochemical Laboratory of the Department of Agriculuture, Kyushu Imperial University

https://doi.org/10.5109/22590

出版情報: 九州大学大学院農学研究院紀要. 6 (3)，pp.95-117，1939-06. Kyushu Imperial University バージョン：

権利関係 : 


\title{
CHEMICAL STUDIES ON CANNED MEATS
}

\author{
Yuzuru OKUDA, Kazuo YaMAFUJI \\ and
}

Kitaro KaTAI

\section{CONTENTS}

Chapter 1. Some Chemical Changes of Muscle Proteins in Canning.

Chapter II. On the Contents of Gases and Metals in Stored Cans.

Chapter III. Carbon Dioxide and Hydrogen Gases Produced at Canning and in Storage.

Chapter IV. Protein, Fat and Nutritive Values of Storaged Canned Meats.

Chapter V. Summary.

\section{Chapter I}

\section{SOME CHEMICAL CHANGES OF MUSCLE PROTEINS IN CANNING '?}

Some changes take place in proteins and extractive matters of meats simply by heating in the case of canning. In this Chapter it is described on the study of the decomposition occurring in the muscle proteins.

The materials were prepared from muscles by removing substances soluble in water, alcohol and ether. The solutions of various $\mathrm{pH}$ values were added to the muscle proteins. The mixtures were sealed tightly in glass tubes and heated at $130-140^{\circ} \mathrm{C}$. The purpose for adding the solutions of various $\mathrm{pH}$ values to the muscle proteins and heating them is to find out the changes of the muscle proteins in different hydrogen ion concentrations, and

i) Y. OKtos and K. Yamaflit: Nippon Nôgeikagaku Kwaisi, 8. 835. 1933. (In Japanese.) 
for using of glass-tubes is to learn the chemical changes free from the infuence of any metallic can-materials.

(i) Changes of the Hydrogen Ion Concenttraions. As the concentration of hydrogen ion of the contents of cans has great influences on etching the tin plated iron sheet of cans and on the chemical changes of the contents which occur during preservation, the experiments were carried out by the electric method for ascertaining the variation of $\mathrm{pH}$ value of muscle proteins by heating.

The proteins of whale, rabbit, hen, sea-bream, yeliow-tail, carp, bonito, cuttle-fish and spiny-lobster were chosen as experimental materials. Either a slightly acidic or alkaline solution or distilled water was added to the proteins before heating. The results of experiments always showed the tendency of $\mathrm{pH}$ to approach towards the neutral value. For example, when the muscle proteins of whale were heated at the $\mathrm{pH}$ values of $3.4,6.2$ (adding water) and 8.5 , the $\mathrm{pH}$ changed to $4.5,6.6$ and 8.1 respectively. Thus, it is considered that these variations were probably due to the volatile basic and acidic substances, such as ammonia and hydrogen sulphide, as well as to the soluble amphoteric electrolytes, such as polypeptide and amino acid produced while heating.

(2) Changes of the Form of Nitrogen. When the muscle proteins of whale, rabbit, cow, hen and mackerel were heated in distilled water at $150^{\circ} \mathrm{C}$ for one hour, about 20 per cent of their protein-nitrogen changed to the forms of peptone, peptide, amino acid and ammonia. The formation of these soluble nitrogenous substances may cause a speedy putrefaction to the opened canned meat. The distribution of nitrogen of the muscle proteins after heating is shown in Table 1 .

Table 1

\begin{tabular}{|c|c|c|c|c|c|c|c|c|c|}
\hline \multirow{2}{*}{$\cdots$} & \multicolumn{5}{|c|}{ In per cent of dry matter } & \multicolumn{4}{|c|}{ In per cent of total $N$} \\
\hline & $\underset{\mathrm{N}}{\text { Total- }}$ & Protein & $\underset{N}{A}$ & $\underset{\text { nia-N }}{\Lambda \text { mmo- }}$ & $\begin{array}{l}\text { Resi- } \\
\text { dual-N }\end{array}$ & $\begin{array}{l}\text { Protein- } \\
\quad \mathrm{N}\end{array}$ & ${ }_{N}^{A \min o-}$ & & $\begin{array}{l}\text { Resi- } \\
\text { dual-N }\end{array}$ \\
\hline Whale & 1 & & & & 2 & 82.69 & 3.18 & 0.55 & 13.58 \\
\hline Rabbit & 1 & & .78 & 0 & 3.73 & 71.47 & 4.91 & 3 & 23.48 \\
\hline Cow & & & & & 1. & 86.62 & 2.60 & 1.7 & 9.00 \\
\hline $\mathrm{He}$ & 6 & & 52 & 0.31 & 2. & 82.44 & 3.08 & 1.83 & 12.63 \\
\hline Hackerel & 16.81 & 14.18 & 0.45 & 0.34 & 1.84 & 84.35 & 2.68 & 2.04 & 10.95 \\
\hline
\end{tabular}


(3) .Changes in the Elementary Composition of Muscle Proteins. In order to ascertain what changes take place in the elementary composition of muscle proteins through heating under pressure, and to find out the effects of $\mathrm{pH}$ values upon these changes, the muscle proteins of whale, rabbit, hen and seabream were heated at the initial $\mathrm{pH}$ values of $3.4,6.2$ and 8.5. The reseults of experiments showed the decrease of their nitrogen and sulphur contents and the amounts of the decrease were particularly marked when the substances were heated in the solutions having the greater values of $\mathrm{pH}$. The results are given in Table 2 .

Table 2

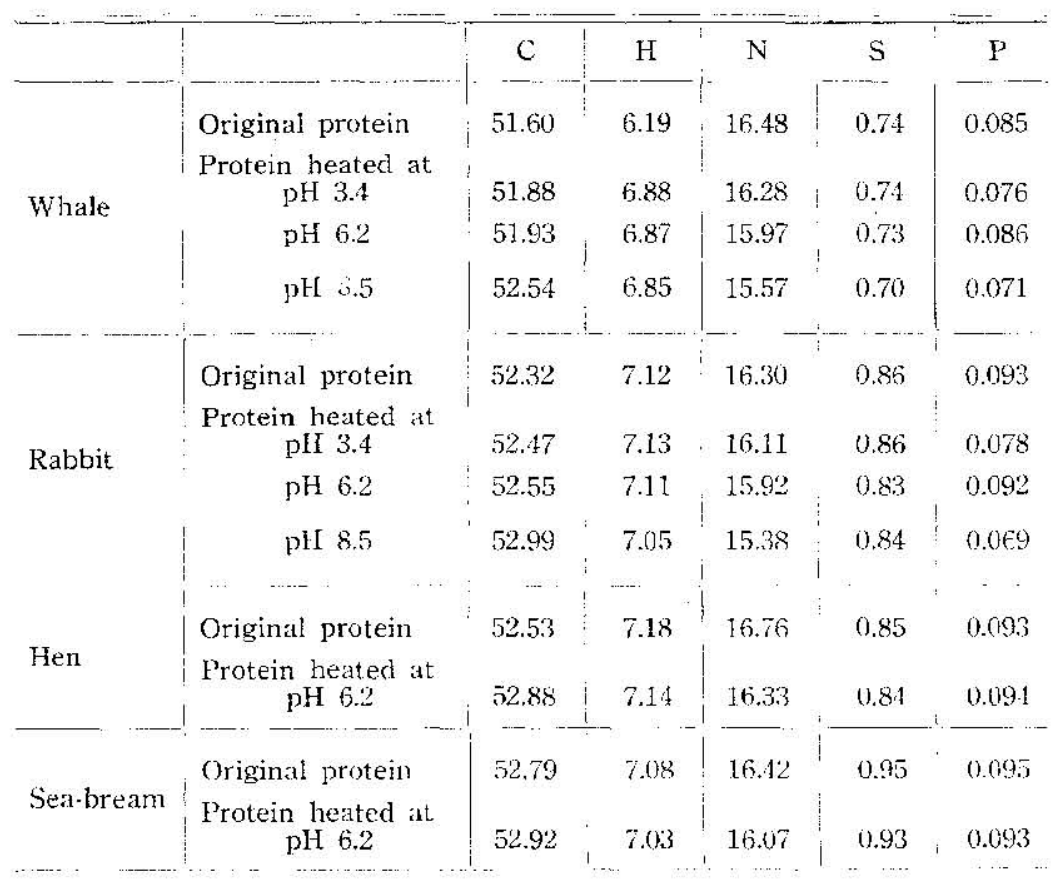

(4) Generation of Ammonia and Hydrogen Sulphide. The results of experiments with four kinds of muscle proteins revealed the fact that both $\mathrm{NH}_{3}$ and $\mathrm{H}_{3} \mathrm{~S}$ were generated in larger quantities when they were heated in the solutions having the greater values 
of $\mathrm{pH}$. This fact agrees with the result of the elementary analysis. When the material of the tin is bad and iron dissolves in the liquid contained in the can, then sulphide of iron preciptates and causes the deterioration and blackening of the canned meats. The amounts of $\mathrm{NH}_{3}$ and $\mathrm{H}_{2} \mathrm{~S}$ in mg. generated from $100 \mathrm{~g}$. of muscle proteins are shown in Table 3.

Table 3

$\mathrm{NH}_{3}$ (mg. in $100 \mathrm{~g}$. of proteins)

\begin{tabular}{c|c|c|c|c}
\hline $\mathrm{pH}$ before heated & Whale & Rabbit & Hen & Sea-bream \\
\cline { 2 - 5 } 3.4 & 0.15 & 0.21 & - & - \\
6.2 & 0.58 & 1.76 & 1.36 & 1.88 \\
8.5 & 28.44 & 36.89 & - & - \\
\hline
\end{tabular}

$\mathrm{H}_{2} \mathrm{~S}$ (mg. in $100 \mathrm{~g}$. of proteins)

\begin{tabular}{c|c|c|c|c}
\hline$\overline{\mathrm{pH} \text { before heated }}$ & Whale & Rabbit & Hen & Sea-bream \\
\hline 3.4 & 0 & 0 & - & - \\
6.2 & 9.37 & 1.14 & 0.87 & 15.62 \\
8.5 & 27.72 & 12.89 & - & - \\
\hline
\end{tabular}

(5) Changes of the Amounts of Arginine, Histidine, Lysine, Cystine, etc. In order to learn how the distributions of arginine, histidine, lysine, cystine and other nitrogen in the muscle proteins of whale, rabbit, hen and sea-bream change by heating, the quantitative analyses were carried out by the Van SLYKI: method before and after the heating. The proteins were heated at three different values of $\mathrm{pH}$ to ascertain the effects of solutions of various $\mathrm{pH}$ upon the proteins. The results are as follows (Table 4). 
Table 4

\begin{tabular}{|c|c|c|c|c|c|c|c|c|c|}
\hline \multicolumn{10}{|c|}{ Whale } \\
\hline & Total $-\mathrm{N}$ & $\begin{array}{l}\text { Ammo- } \\
\operatorname{nia}-\mathrm{N}\end{array}$ & $\left|\begin{array}{c}\text { Mela- } \\
\text { nine-N }\end{array}\right|$ & $\begin{array}{l}\text { Cys- } \\
\text { tine-N }\end{array}$ & $\begin{array}{l}\text { Argi- } \\
\text { uine-N }\end{array}$ & $\begin{array}{l}\text { Histi- } \\
\text { dine-N }\end{array}$ & $\begin{array}{l}\text { Ly- } \\
\text { sine-N }\end{array}$ & $\begin{array}{l}\text { Mono- } \\
\text { amino- } \mathrm{N}\end{array}$ & $\begin{array}{c}\text { Non- } \\
\text { amino-N }\end{array}$ \\
\hline $\begin{array}{l}\text { In per cent of protein } \\
\text { Original protein }\end{array}$ & 16.48 & 0.69 & 0.33 & 0.29 & 2.49 & 2.20 & 1.34 & 8.02 & 1.18 \\
\hline $\begin{array}{c}\text { Protein heated at } \\
\text { pH } 3.4\end{array}$ & 16.28 & 0.59 & 0.45 & 0.16 & 2.59 & 2.28 & 1.16 & 7.79 & 1.23 \\
\hline pl1 6.2 & 15.67 & 0.55 & 0.44 & 0.14 & 2.36 & 2.36 & 1.26 & 7.66 & 1.21 \\
\hline $\mathrm{pH} 8.5$ & 15.57 & 0.45 & 0.43 & 0.10 & 2.49 & 1.96 & 1.34 & 7.45 & 1.35 \\
\hline $\begin{array}{l}\text { In per cent of total } \mathrm{N} \\
\text { Original protein }\end{array}$ & 100 & 4.29 & 2.02 & 1.45 & 15.08 & 13.37 & 8.15 & 48.66 & 7.15 \\
\hline $\begin{array}{c}\text { Protein heated at } \\
\mathrm{pH} 3.4\end{array}$ & 100 & 3.62 & 2.79 & 1.04 & 15.94 & 14.03 & 6.48 & 47.84 & 7.67 \\
\hline pH 6.2 & 100 & 3.42 & 2.73 & 0.87 & 14.77 & 14.79 & 7.88 & 47.95 & 7.57 \\
\hline pH 8.5 & 100 & 2.91 & 2.73 & 0.64 & 15.97 & 12.59 & 8.62 & 47.85 & 8.64 \\
\hline \multicolumn{10}{|c|}{ Rabbit } \\
\hline $\begin{array}{l}\text { In per cent of protein } \\
\text { Original protein }\end{array}$ & 16.30 & 0.74 & 0.36 & 0.19 & 2.49 & 1.93 & 1.26 & 8.17 & 1.15 \\
\hline $\begin{array}{l}\text { Protein heated at } \\
\text { pII } 3.4\end{array}$ & 16.11 & 0.73 & 0.46 & 0.15 & 2.58 & 1.92 & 0.94 & 7.82 & 1.41 \\
\hline $\mathrm{pH} \quad 6.2$ & 15.92 & 0.50 & 0.38 & 0.13 & 2.34 & 2.17 & 1.15 & 7.89 & 1.34 \\
\hline pH 8.5 & 15.38 & 0.39 & 0.43 & 0.10 & 2.49 & 1.75 & 1.23 & 7.59 & 1.41 \\
\hline $\begin{array}{l}\text { In per cent of total } \mathrm{N} \\
\text { Original protein }\end{array}$ & 100 & 4.56 & 2.17 & 0.18 & 15.28 & 11.85 & 7.74 & 50.15 & 7.06 \\
\hline $\begin{array}{l}\text { Protein heated at } \\
\mathrm{pH} 3.4\end{array}$ & 100 & 4.55 & 2.83 & 0.92 & 16.04 & 12.53 & 6.04 & 48.45 & 8.78 \\
\hline $\mathrm{pH} 6.2$ & 100 & 3.81 & 2.36 & 0.79 & 14.41 & 13.60 & 6.92 & 49.61 & 8.43 \\
\hline pH 8.5 & 100 & 2.57 & 2.77 & 0.65 & 16.16 & 11.38 & 8.02 & 49.32 & 9.18 \\
\hline \multicolumn{10}{|c|}{ Hen } \\
\hline $\begin{array}{l}\text { In per cent of protein } \\
\text { Original protein }\end{array}$ & 16.76 & 1.10 & 0.48 & 0.18 & 2.71 & 1.97 & 1.36 & 8.19 & 0.76 \\
\hline $\begin{array}{c}\text { Protein heated at } \\
\mathrm{pH} 6.2\end{array}$ & 16.33 & 0.89 & 0.63 & 0.14 & 255 & 2.04 & 1.15 & 7.97 & 0.97 \\
\hline $\begin{array}{l}\text { In per cent of total } N \\
\text { Original protein }\end{array}$ & 100 & 6.58 & 2.85 & 1.07 & 16.14 & 11.73 & 8.12 & 49.60 & 4.53 \\
\hline $\begin{array}{l}\text { Protein heated at } \\
\text { pH } 6.2\end{array}$ & 100 & 5.42 & 3.88 & 0.85 & 15.61 & 12.51 & 7.04 & 48.78 & 5.95 \\
\hline
\end{tabular}


Sea-bream

\begin{tabular}{|c|c|c|c|c|c|c|c|c|c|}
\hline \multirow{2}{*}{$\begin{array}{l}\text { In per cent of protein } \\
\text { Original protein } \\
\text { Protein heated at } \\
\text { pH } 6.2\end{array}$} & 16.42 & 0.77 & 0.36 & 0.28 & 2.54 & 2.24 & 1.47 & 8.35 & 0.42 \\
\hline & 16.07 & 0.45 & 0.48 & 0.12 & 2.46 & 2.36 & 1.37 & 8.20 & 0.51 \\
\hline $\begin{array}{l}\text { In per cent of total } N \\
\text { Original protein }\end{array}$ & 100 & 4.70 & 2.17 & 1.69 & 15.46 & 13.61 & 8.92 & 50.83 & 2.55 \\
\hline $\begin{array}{c}\text { Protein heated at } \\
\mathrm{pH} 6.2\end{array}$ & 100 & 3.43 & 2.99 & 0.77 & 14.68 & 14.71 & $\begin{array}{r}7.93 \\
-\quad\end{array}$ & 50.42 & 3.17 \\
\hline
\end{tabular}

It was found that the total nitrogen, ammonia and cystine nitrogen always decrease by heating, and the higher the value of $\mathrm{pH}$ the greater the rate of the decrease, while melanine nitrogen generally increases. The amounts of cystine, arginine, histidine and lysine contained in the proteins before and after heating were calculated in per cent from the above results.

Table 5

\begin{tabular}{|c|c|c|c|c|c|}
\hline & & Cystine & Arginine & Histidine & Lysine \\
\hline \multirow{4}{*}{ Whale } & Original protein & 2.49 & 7.74 & 8.12 & 6.99 \\
\hline & Protein heated at pH 3.4 & 1.37 & 8.04 & 8.41 & 6.05 \\
\hline & pH 6.2 & 1.20 & 7.33 & 8.71 & 6.57 \\
\hline & pH 8.5 & 0.86 & 7.74 & 7.23 & 6.99 \\
\hline \multirow{4}{*}{ Rabit } & Original protein & 1.€3 & 7.74 & 7.11 & $6.5 \bar{i}$ \\
\hline & Protein heated at $\mathrm{pH} 3.4$ & 1.29 & 8.02 & 7.09 & 4.90 \\
\hline & $\mathrm{pH} 6.2$ & 1.11 & 7.27 & 8.01 & 6.00 \\
\hline & $\mathrm{pH} 8.5$ & 0.85 & 7.74 & 6.46 & 6.41 \\
\hline \multirow{2}{*}{ Hen } & Original protein & 1.54 & 8.42 & 7.27 & 7.09 \\
\hline & Protein heated at $\mathrm{pH} 6.2$ & 1.20 & 7.92 & 7.53 & 6.00 \\
\hline \multirow{2}{*}{ Sea-bream } & Original protein & 2.40 & 7.89 & 8.27 & 7.67 \\
\hline & Protein heated at $\mathrm{pH} 6.2$ & 1.03 & 7.64 & 8.71 & 7.14 \\
\hline
\end{tabular}


According to Table 5, the quantities of cystine, arginine, histidine and lysine containcd in the proteins after heating showed a tendency of decrease, as compared with those contained in the original proteins. Such tendencies wcre remarkable on cystinc at the higher $\mathrm{pH}$ before heating and on lysine at the lower $\mathrm{pH}$.

(6) Changes of Tyrosine and Tryptophane. The quantities of tyrosine and tryptophane contained in the muscle proteins of whale, hen, rabbit, yellow-tail, carp, bonito, sea-bream, cuttle-fish and spiny-lobster were determined before and after heating. The amounts of those amino acids decreased by heating, but very little, as it is obvious in Table 6.

Table 6

\begin{tabular}{|c|c|c|c|c|c|c|}
\hline \multirow[b]{2}{*}{ Proteins } & \multicolumn{2}{|c|}{ Tyrosine } & \multicolumn{2}{|c|}{ Tryptophane } & \multicolumn{2}{|c|}{$\mathrm{pH}$} \\
\hline & $\begin{array}{l}\text { Before } \\
\text { heating }\end{array}$ & $\begin{array}{c}\text { After } \\
\text { heating }\end{array}$ & $\begin{array}{l}\text { Before } \\
\text { heating }\end{array}$ & $\begin{array}{c}\text { After } \\
\text { heating }\end{array}$ & $\begin{array}{l}\text { Before } \\
\text { heating }\end{array}$ & $\begin{array}{c}\text { After } \\
\text { heating }\end{array}$ \\
\hline Whale & 5.11 & 4.97 & 1.51 & 1.32 & 6.2 & 6.6 \\
\hline Hen & 4.81 & 4.78 & 1.58 & 1.59 & 6.2 & 6.6 \\
\hline Rabbit & 5.49 & 527 & 1.68 & 1.57 & 6.2 & 6.6 \\
\hline Yellow-tail & 4.97 & 4.69 & 1.70 & 1.62 & 6.51 & 6.54 \\
\hline Carp & 4.71 & 4.53 & 1.50 & 1.47 & 5.02 & 5.92 \\
\hline Bonito & 4.84 & 4.60 & 1.63 & 1.46 & 7.17 & 6.65 \\
\hline Sea-bream & 5.00 & 4.74 & 1.63 & 1.56 & 6.37 & 6.51 \\
\hline Cuttle-fish & 4.83 & 4.71 & 1.37 & 1.29 & 4.67 & 5.57 \\
\hline Spiny-lobster & 5.05 & 4.81 & 1.46 & 1.34 & 3.98 & 5.29 \\
\hline
\end{tabular}

(7) Changes of Proline. The experiments carried out by using each $40 \mathrm{~g}$. of gelatine to find out the difference between the quantities of proline contained in the materials before and after heating. It was observed that there was almost no. difference between them, and when the pure solution of proline was heated, there was no detectable decomposition. Therefore the amount of proline in muscle proteins may probably be the same.

(8) Changes of the Forms of Cysteine, Cystine and Sulphur. When the solutions of pure cysteine and cystine were heated 
under the different $\mathrm{pH}$, a part of the one always changed into the other. That is, when the solution of any of the two acids was heated, it was found that the solution contained the both acids, but the sum of the two quantities always decreascd. The results of the experiments are as follows:

\section{Table 7}

\begin{tabular}{|c|c|c|c|c|c|}
\hline \multirow{2}{*}{$\begin{array}{c}\mathrm{pH} \\
\text { before heating }\end{array}$} & \multirow{2}{*}{ Sample } & \multirow{2}{*}{ Used, my. } & \multicolumn{2}{|c|}{ Found, mg. } & \multirow{2}{*}{ Sum } \\
\hline & & & Cysteine & Cystine & \\
\hline 1.7 & Cysteine & 37.5 & 32.0 & 3.8 & 35.8 \\
\hline 4.8 & Cystine & 45.6 & 2.9 & 39.9 & 42.8 \\
\hline 6.8 & Cysteine & 25.1 & 9.4 & 6.6 & 16.0 \\
\hline 6.8 & Cystine & 22.6 & 2.7 & 17.1 & 19.8 \\
\hline 8.3 & Cysteine & 25.8 & 5.1 & 5.3 & 10.4 \\
\hline 8.6 & Cystine & 25.0 & 2.7 & 16.2 & 19.2 \\
\hline
\end{tabular}

The muscle proteins of sea-bream were heated at $\mathrm{pH} 6.1$ (a) and 9.2 (b), and the forms of sulphur were determined. The results obtained are as follows:

Table 8

\begin{tabular}{|c|c|c|c|c|c|c|c|c|c|}
\hline $\begin{array}{l}\text { Mg. per cent. of } \\
\text { protein }\end{array}$ & $\begin{array}{l}\text { Total } \\
\mathrm{S}\end{array}$ & Cysteine & Cyst & & $\underset{\mathrm{S}}{\mathrm{H}_{2} \mathrm{~S}}$ & \multicolumn{2}{|c|}{$\underset{\mathrm{S}}{\text { Sulphide }}$} & $\underset{\mathrm{S}}{\text { Sulphate }}$ & $\begin{array}{c}\text { Soluble- } \\
\text { organic S }\end{array}$ \\
\hline Before heating & 690 & 660 & 19 & & - & & - & - & - \\
\hline After heating (a) & - & 493 & 20 & & 6.6 & & 0.4 & 18 & 96 \\
\hline$" \quad, \quad(b)$ & - & 440 & 11 & & 20.9 & & 4.6 & 30 & 103 \\
\hline $\begin{array}{l}\text { In per cent. of } \\
\text { total S }\end{array}$ & $\begin{array}{l}\text { Cotal } \\
\mathrm{S}\end{array}$ & ysteine $\mathrm{Cy}$ & stine & $\mathrm{H}_{\mathrm{S}}$ & Su & $\begin{array}{l}\text { phide } \\
\mathrm{S}\end{array}$ & Sulphat & $\begin{array}{l}\text { te Soluble } \\
\text { organic }\end{array}$ & S Protein \\
\hline Before heating & 100 & 26.0 & 7.2 & - & & - & - & - & - \\
\hline After heating (a) & - & 19.0 & 7.5 & 09 & & 0.06 & 2.6 & 14.0 & 82.4 \\
\hline , $\quad, \quad(b)^{\prime}$ & - & 17.5 & 4.3 & 26.9 & & 0.7 & 4.3 & 15.0 & 77.1 \\
\hline
\end{tabular}


Namely, when it was heated in alkaline solutions, the decompositions of cysteine and cystine were especially considerable, and hydrogen sulphide and other sulphides were formed in large quantities.

\section{Chapter II}

\section{ON THE CONTENTS OF GASES AND METALS IN STORED CANS?}

This chapter deals with the contents of gases and metals in the cans which have endured long storage.

As a means to know the changes of canned meats and the state of corrosion of can-materials, gases, such as carbon dioxide, hydrogen, oxygen and nitrogen, sometimes ammonia and hydrogen sulphide, together with metals, such as iron and tin, dissolved from cans were determined with the results shown in Tables 1,2 and 3 .

Table 1

Beef. (+ : present; -- : absent)

\begin{tabular}{|c|c|c|c|c|}
\hline Age of cans (years) ............... & 15 & 7 & 5 & 1 \\
\hline 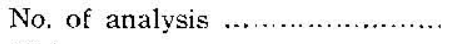 & 6 & 7 & 3 & 3 \\
\hline 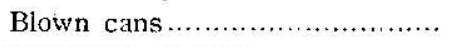 & + & - & - & -- \\
\hline Corrosion of cans ...................... & $++t$ & ++ & $+t$ & + \\
\hline Putrid oder ........................... & - & -- & - & $\rightarrow$ \\
\hline Appearance of meat ... & Normal & Normal & Normal & Normal \\
\hline (g.) $\cdots \cdots \cdots \cdots, \ldots, \ldots$ & 156 & 159 & 450 & 459 \\
\hline$(\%) \ldots \ldots \ldots \ldots \ldots \ldots$ & 61.0 & 60.5 & 60.2 & 59.7 \\
\hline Dry matter & 39.0 & 39.5 & 39.8 & 40.3 \\
\hline (c.c.) $\ldots \ldots \ldots \ldots \ldots \ldots \ldots$ & 79.5 & 25.9 & 15.9 & 10.4 \\
\hline$(\%) \ldots \ldots \ldots \ldots \ldots \ldots$ & 3.4 & 4.9 & 3.6 & 2.8 \\
\hline , $\quad \cdots+\ldots \ldots \ldots+\ldots, \ldots$ & 1.3 & 1.8 & 3.0 & 4.7 \\
\hline,$\quad \cdots \cdots \cdots+\ldots+\cdots \cdots$ & 82.2 & 22.3 & 22.3 & 12.2 \\
\hline$" \quad \cdots$ & 13.2 & 71.0 & 71.2 & 80.4 \\
\hline img. $\%$ o $\ldots \ldots \ldots \ldots \ldots \ldots$ & $19 \mathbf{i} .5$ & 15.6 & 14.2 & 13.7 \\
\hline 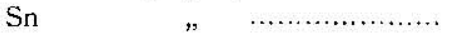 & 375.0 & 219.5 & 104.5 & 78.3 \\
\hline$\ldots \ldots \ldots \ldots \ldots \ldots$ & 5.8 & 5.6 & $5.8^{\circ}$ & 5.8 \\
\hline
\end{tabular}

Table 2

Crab

Age of cans (years)

5

No. of analysis

$6 \quad 4 \quad 6$

2) Y. Okuts and K. KatsI: Nippon Nôgeikagaku Kwaisi, 12. 1059. 1936. (In Japanese.) 
104 Yuzuru OKuDa, Kazuo YamajujI and Kitaro Katal

\begin{tabular}{|c|c|c|c|c|}
\hline Contents & (g.) & 231 & 221 & 224 \\
\hline Water & 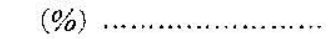 & 79.2 & 78.5 & 80.0 \\
\hline Dry matte & , & 20.8 & 21.5 & 2010 \\
\hline Gas & (c.c.) & 9.5 & 7.0 & 11.0 \\
\hline $\mathrm{CO}_{2}$ & $(\%)$ & 0.3 & 0.6 & 0.4 \\
\hline $\mathrm{O}_{2}$ & 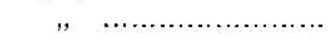 & 9.6 & 7.2 & 10.1 \\
\hline $\mathrm{H}_{2}$ & $\ldots \ldots \ldots \ldots \ldots \ldots \ldots$ & 11.6 & 11.9 & 8.7 \\
\hline $\mathrm{N}_{2}$ & 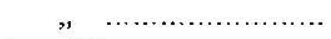 & 78.5 & 80.4 & 898 \\
\hline $\mathrm{Fe}$ & $\left(\right.$ mg. $\left.q_{0}^{\prime}\right) \ldots \ldots \ldots \ldots \ldots \ldots \ldots \ldots$ & 106 & 11.3 & 9.7 \\
\hline $\mathrm{Sn}$ & $" \quad \ldots \ldots \ldots \ldots \ldots \ldots \ldots$ & 19.9 & 17.9 & 15.0 \\
\hline $\mathrm{pH}$ & $\ldots \ldots \ldots \ldots \ldots$ & 69 & 6.9 & 7.0 \\
\hline
\end{tabular}

Table 3

Salmon and Tuniny

\begin{tabular}{|c|c|c|c|c|c|}
\hline \multirow{2}{*}{\multicolumn{2}{|c|}{ Age of cans (years) $\ldots \ldots \ldots \ldots \ldots \ldots$}} & \multicolumn{2}{|c|}{ Salmon } & \multicolumn{2}{|c|}{ Tunny } \\
\hline & & 1 & 7 & 1 & 7 \\
\hline Contents & (g.) & 452 & 480 & 404 & 422 \\
\hline Water & $(\%) \quad \ldots \ldots \ldots \ldots \ldots \ldots$ & 73.7 & 75.2 & 62.4 & 61.1 \\
\hline Dry matter & , $\quad \ldots \ldots \ldots \ldots \ldots \ldots \ldots$ & 26.3 & 24.8 & 37.6 & 38.9 \\
\hline Gas & (c.c.) $\ldots \ldots \ldots \ldots \ldots \ldots$ & 1.5 & 5.0 & 21.5 & 102.0 \\
\hline $\mathrm{CO}_{t}$ & $(\%)$ & 0 & 1.8 & 13.1 & 5.5 \\
\hline $\mathrm{O}_{2}$ &,$\quad \ldots \ldots \ldots \ldots \ldots \ldots \ldots \ldots$ & 6.7 & 10.2 & 0.7 & 0.3 \\
\hline $\mathrm{H}_{2}$ & " & 35.3 & 25.0 & 20.8 & 73.8 \\
\hline $\mathrm{N}_{2}$ & , ………............ & 58.0 & 63.0 & 65.4 & 20.4 \\
\hline $\mathrm{Fe}$ & (mg. \%) & 13.8 & 15.9 & 12.7 & 49.9 \\
\hline Sn & , & 24.2 & 108.7 & 87.0 & 214.8 \\
\hline
\end{tabular}

\section{Chapter III}

\section{CARBON DIOXIDE AND HYDROGEN GASES PRODUCED AT CANNING AND IN STORAGE}

For the purpose of knowing the changes of canned meat and the state of corrosion of can-materials, we determined oxygen, nitrogen, carbon dioxide and hydrogen gases in commercial cans as described in the preceding chapter. In the experiment recorded in this chapter, carbon dioxide was again determined as a means of knowing some chemical changes which occurred in canned meat, and hydrogen gas to know the state of the corrosion of can-material. But in the present case, instead of commercial cans, sealed glass tubes containing $5 \mathrm{~g}$. of meat powder, $0.5 \mathrm{~g}$. each of

3) Y. OKuba and K. Katai: Nippon Nôgeikagaku Kwaisi, 12. 1064. 1936. (In Japanese.) 
tin and iron powders, and solutions of different hydrogen ion concentrations were used for the sake of more exact comparison. The tubes were heated at $130^{\circ}$ for different hours, to know the influence of heat and pressure upon canned meat and can-material at canning, and preserved at $50^{\circ}$ for different periods to know the effect of storage.

The experiments were performed with three kinds of meats, but only the data with beef are described below, as the results with other meats were analogous.

\section{Table 1}

\section{Carbon Dioxide (c.c.)}

(a) Sulphuric acid was added

\begin{tabular}{|c|c|c|c|c|c|c|c|c|}
\hline Meat powder & \multicolumn{4}{|c|}{ Fresh meat } & \multicolumn{4}{|c|}{ Somewhat spoiled meat } \\
\hline $\mathrm{pH}$. before and after heating & \multicolumn{4}{|c|}{$4.0-4.5$} & \multicolumn{4}{|c|}{$4.0-4.3$} \\
\hline Hours of heating & & 1 & & 3 & & 1 & & 3 \\
\hline Days of storage & 0 & 30 & 60 & 0 & 0 & 30 & 60 & 0 \\
\hline Fe added & 2.1 & 2.6 & 2.1 & 3.1 & 2.2 & 2.1 & 1.8 & 2.7 \\
\hline Sn added & 1.4 & 2.6 & 2.9 & 2.2 & 1.1 & 1.9 & 2.5 & 1.8 \\
\hline $\mathrm{Fe}$ and $\mathrm{Sn}$ added & 2.2 & 2.2 & 1.9 & 3.1 & 2.0 & 2.1 & 1.5 & 2.8 \\
\hline
\end{tabular}

(b) Water was added

\begin{tabular}{|c|c|c|c|c|c|c|c|c|}
\hline Meat powder & \multicolumn{4}{|c|}{ Fresh meat } & \multicolumn{4}{|c|}{ Somewhat spoiled meat } \\
\hline $\mathrm{pH}$. before and after heating & & 5.5 & & & & & & \\
\hline Hours of heating & & 1 & & 3 & & 1 & & 3 \\
\hline Days of storage & 0 & 30 & 60 & 0 & 0 & 30 & 60 & 0 \\
\hline Fe added & 1.7 & 1.2 & 0.8 & 2.6 & 1.7 & 1.1 & 1.2 & 2.5 \\
\hline
\end{tabular}




\begin{tabular}{l|r|r|r|r|r|r|r|r}
\hline Sn added & 1.5 & 2.4 & 2.8 & 2.3 & 1.2 & 2.0 & 2.4 & 2.0 \\
\hline Fe and Sn added. & 1.5 & 0.5 & 0.9 & 2.4 & 1.4 & 0.8 & 0.8 & 2.4 \\
\hline
\end{tabular}

(c) Sodium hydroxide was added.

\begin{tabular}{|c|c|c|c|c|c|c|c|c|}
\hline Meat powder & \multicolumn{4}{|c|}{ Fresh meat } & \multicolumn{4}{|c|}{ Somewhat spoiled meat } \\
\hline $\mathrm{pH}$, before and after heating & \multicolumn{4}{|c|}{$8.5-7.9$} & \multicolumn{4}{|c|}{$8.2-7.9$} \\
\hline Hours of heating & & 1 & & 3 & & 1 & & 3 \\
\hline Days of storage & 0 & 30 & 60 & 0 & 0 & 30 & 60 & 0 \\
\hline Fe added & 0.9 & 0.5 & 0.2 & 1.8 & 1.1 & 0.3 & 0.2 & 2.0 \\
\hline Sn added & 0.9 & 1.2 & 1.3 & 1.6 & 1.0 & 1.4 & 1.8 & 1.8 \\
\hline $\mathrm{Fe}$ and $\mathrm{Sn}$ added & 0.9 & 0.3 & 0.2 & 1.4 & 1.2 & 0.5 & 0.2 & 2.0 \\
\hline
\end{tabular}

\section{Table 2}

Hydrogen (c.c.)

(a) Sulphuric acid was added.

\begin{tabular}{|c|c|c|c|c|c|c|c|c|}
\hline Meat powder & \multicolumn{4}{|c|}{ Fresh meat } & \multicolumn{4}{|c|}{ Somewhat spoiled meat } \\
\hline $\mathrm{pH}$, before and after heating & \multicolumn{4}{|c|}{$4.0-4.5$} & \multicolumn{4}{|c|}{$4.0-4.3$} \\
\hline Hours of heating & & 1 & & 3 & & 1. & & 3 \\
\hline Days of storage & 0 & 30 & 60 & 0 & 0 & 30 & 60 & 0 \\
\hline Fe added & 18.6 & 48.2 & 57.7 & $32 . \overline{5}$ & 19.9 & 55.0 & 60.1 & 30.2 \\
\hline Sn added & 0.3 & 0.2 & 0.2 & 0.3 & 0.3 & 0.3 & 0.1 & 0.3 \\
\hline $\mathrm{Fe}$ and $\mathrm{Sn}$ added & 19.7 & 49.3 & 57.8 & 32.8 & 23.7 & 54.1 & 63.3 & 27.8 \\
\hline
\end{tabular}


(b) Water was added.

\begin{tabular}{|c|c|c|c|c|c|c|c|c|}
\hline \multirow{2}{*}{ Meat powder } & \multirow{2}{*}{\multicolumn{4}{|c|}{$\begin{array}{l}\text { Fresh meat } \\
5.5-5.7\end{array}$}} & \multicolumn{4}{|c|}{ Somewhat spoiled meat } \\
\hline & & & & & & $5.5-$ & & \\
\hline Hours of heating & & 1 & & 3 & & 1 & & 3 \\
\hline Days of storage & 0 & 30 & 60 & 0 & 0 & 30 & 60 & 0 \\
\hline$\cdots$ & -. & & & & & $-\cdots$ & & \\
\hline $\mathrm{Fe}$ added & 5.2 & 32.1 & 36.0 & 7.4 & 5.9 & 34.9 & 41.1 & 8.1 \\
\hline Sn added & 0.2 & 0.2 & 1.2 & 0.3 & 0.2 & 0.1 & 0.5 & 0.2 \\
\hline $\mathrm{Fe}$ and $\mathrm{Sn}$ added & 5.2 & 33.4 & 33.0 & 8.7 & 5.6 & 40.0 & 41.6 & 9.6 \\
\hline
\end{tabular}

(c) Sodium hydroxide was added.

\begin{tabular}{|c|c|c|c|c|c|c|c|c|}
\hline Meat powder & \multicolumn{4}{|c|}{ Fresh meat } & \multicolumn{4}{|c|}{ Somewhat spoiled meat } \\
\hline $\mathrm{pH}$, before and after heating & \multicolumn{4}{|c|}{$8.5-7.9$} & \multicolumn{4}{|c|}{$8.2-7.9$} \\
\hline Hours of heating & \multicolumn{3}{|c|}{1} & 3 & \multicolumn{3}{|c|}{1} & 3 \\
\hline Days of storage & 0 & 30 & 60 & 0 & 0 & 30 & 60 & 0 \\
\hline $\mathrm{Fe}$ added & 0.5 & 16.4 & 21.5 & 1.2 & 1.8 & 22.9 & 27.1 & 52 \\
\hline Sn added & 0.2 & 0.1 & 0 & 0.2 & 0 & 0 & 0.1 & 0.2 \\
\hline $\mathrm{Fe}$ and $\mathrm{Sn}$ added & 0.9 & 17.2 & 21.2 & 0.8 & 1.4 & 22.1 & 27.8 & 5.1 \\
\hline
\end{tabular}

\section{Chapter IV \\ PROTEIN, FAT AND NUTRITIVE VALUES OF STORAGED \\ CANNED MEATS $4 ?$}

1. Protein

a) The experiments were carried out with canned beef of different ages of storage, from 2 to 15 years. The meats were

() Y. Oкьәм: Represajo de la Bulteno Scienca de la Fakultato Terkultura, Kjuŝu Imperia Universitato, Vol. 8, No. 1. Julio, 1938. (In Japanese.) 
dried, pulverized, and analysed with the following results which are described in per cent of dry matter.

Table 1

\begin{tabular}{c|c|c|c|c}
$\begin{array}{c}\text { Age of } \\
\text { cans }\end{array}$ & $\begin{array}{c}\text { Total } \\
\text { nitrogen }\end{array}$ & Crude protein & Crude fat & Ash \\
\hline 15 & $10.86 \%$ & $67.88 \%$ & $8.89 \%$ & $1094 \%$ \\
10 & 11.29 & 70.56 & 9.16 & 8.85 \\
7 & 10.28 & 64.25 & 12.22 & 13.24 \\
5 & 10.42 & 65.13 & 12.56 & 12.07 \\
2 & 10.72 & 6700 & 9.50 & 11.79
\end{tabular}

b) Crude proteins were obtained from canned and fresh beef by boiling with water faintly acidified with acetic acid, and by extracting several times with alcohol and ether. Ash and nitrogen contents of the proteins were determined as mentioned below.

Table 2

\begin{tabular}{|c|c|c|c|}
\hline \multirow{2}{*}{$\begin{array}{l}\text { Age of } \\
\text { Cans }\end{array}$} & \multicolumn{2}{|c|}{ In dry matter } & \multirow{2}{*}{$\begin{array}{l}\text { In ash and mois- } \\
\text { ture free substance } \\
\text { Total nitrogen }\end{array}$} \\
\hline & Ash & Total nitrogen & \\
\hline 15 & $1.78 \%$ & $15.37 \%$ & $15.65 \%$ \\
\hline 10 & 0.91 & 15.77 & 15.91 \\
\hline 7 & 0.95 & 15.77 & 15.92 \\
\hline 5 & 0.56 & 15.48 & 15.57 \\
\hline 2 & 0.38 & 15.58 & 15.63 \\
\hline $\begin{array}{c}\text { Fresh } \\
\text { meat }\end{array}$ & 0.25 & 15.78 & 15.82 \\
\hline
\end{tabular}

From the result of experiments we see that the nitrogen content of the proteins obtained from canned and fresh meats is 
nearly equal, while their ash content is higher the older the cans. This result concerning the ash content is in accord with the fact set forth in Chapter II, namely that the dissolved quantities of iron and tin arising from the corrosion of can-materials is in proportion to the age of cans.

c) Each protein was subjected to analysis by the Van SLYKE method with the following results.

Table 3

In ash and moisture free proteins

\begin{tabular}{|c|c|c|c|c|c|c|}
\hline Age of cans & 15 & 10 & 7 & 5 & 2 & Fresh meat \\
\hline 'Total-N & 15.65 & 15.91 & 15.92 & 15.57 & 15.63 & 15.82 \\
\hline Amide-N & 0.97 & 0.98 & 1.00 & 1.00 & I.03. & 1.06 \\
\hline Insoluble-Humine- $N$ & 0.07 & 007 & 0.07 & 008 & $0.08^{\circ}$ & 0.07 \\
\hline Soluble-Iuimine-N & 0.34 & 0.24 & 0.32 & 0.25 & 0.25 & 0.13 \\
\hline Arginine- $\mathrm{N}$ & 2.07 & 2.10 & 2.04 & 207 & 2.05 & 2.05 \\
\hline Cystine. $\mathrm{N}$ & 0.14 & 0.14 & 0.14 & 0.15 & 0.14 & 0.14 \\
\hline Histidine $-\mathrm{N}$ & 1.03 & 0.94 & 1.11 & 1.04 & 1.08 & 0.92 \\
\hline Lysine $-N$ & 1.89 & 1.94 & 1.80 & 1.80 & 1.82 & 203 \\
\hline Mono-amino- $\mathrm{N}$ & 8.59 & 8.86 & 8.76 & 8.78 & 8.65 & 8.92 \\
\hline Non-amino-N & 0.63 & 0.50 & 0.57 & 0.36 & 0.50 & 0.49 \\
\hline Sum & 15.64 & 15.77 & 15.81 & 15.53 & $1 \overline{5} .60$ & 15.81 \\
\hline
\end{tabular}

In per cent of total nitrogen

\begin{tabular}{|c|c|c|c|c|c|c|}
\hline Age of cans & 15 & 10 & 7 & 5 & 2 & Fresh meat \\
\hline Total-N & 100 & 100 & 100 & 100 & 100 & 100 \\
\hline Amide $\cdot \mathrm{N}$ & 6.20 & 6.16 & 6.28 & 6.42 & 6.59 & 6.70 \\
\hline Insoluble- Humine-N & 0.45 & 0.44 & 0.44 & 0.51 & 0.51 & 0.44 \\
\hline Soluble-lfumine-N & 2.17 & 1.51 & 2.01 & 1.61 & 1.60 & 0.82 \\
\hline Arginine-N & 13.23 & 13.20 & 12.81 & 13.29 & 13.12 & 12.96 \\
\hline Cystine-. $\mathrm{N}$ & 0.89 & 0.88 & 0.88 & 0.96 & 0.90 & 0.88 \\
\hline Ifistidine- $\mathrm{N}$ & 6.58 & 5.91 & 6.97 & 6.68 & 6.91 & 5.82 \\
\hline Lysine $-\bar{N}$ & 11.50 & 12.19 & 11.31 & 11.56 & 11.64 & $1 \overline{2} 83$ \\
\hline Mono-amino-N & 54.89 & 55.69 & 55.03 & 56.39 & 55.34 & 56.38 \\
\hline Non-amino-N & 4.03 & 3.14 & 3.58 & 2.31 & 3.20 & 3.10 \\
\hline Sum & 99.94 & 99.12 & 99.31 & 99.73 & 99.81 & 9993 \\
\hline
\end{tabular}

From the analytical results we see that no remarkable quantitative difference was to be observed among the protaines obtained 
from the canned meats of different ages and the fresh meat. This fact brought out the conclusion that the proteins obtained from them have nearly equal nutritive value. This conclusion parallels that obtained from feeding experiments performed long years age ${ }^{\text {.). }}$.

\section{Fat}

(a) The iodine value and acid value were determined in the fats obtained from canned beef of different ages of storage, from 2 to 15 years, with the following results.

Table 4

\begin{tabular}{c|c|c}
\hline Age of cans & Acid value & Iodine value \\
\hline 15 & 30.45 & 49.08 \\
10 & 25.47 & 48.10 \\
7 & 13.67 & 45.85 \\
5 & 11.40 & 43.65 \\
2 & 10.44 & 4598 \\
\hline
\end{tabular}

From these results we see that the acid value increases appreciably with the length of the storage of the cans.

(b) We examined two groups of cans of beef both of which had been stored for 6 years. One of these was normal, but the other swollen abnormally, becoming convex at the ends, by the pressure of hydrogen gas evolved from can-materials by corrosion. For the purpose to comparing the chemical properties, fat was obtained by extracting with ether, dehydrating with anhydrous sodium sulphate, and evaporating the ether in carbon dioxide gas at diminished pressure. The results of determination of these fats together with that of the fat of fresh beef are shown in the following table:

5) U. Suzliki, Y. Okuda, T. Okimit, and T. Nagasawa: Tokio Kagakukwaisi ; 40, 385, 1919. (In Japanese.) 
Table 5

\begin{tabular}{|c|c|c|c|}
\hline \multirow[t]{2}{*}{ - } & \multirow{2}{*}{ Fresh meat } & \multicolumn{2}{|c|}{ Canned meat } \\
\hline & & Normal & Blown \\
\hline Acid value & 11.61 & $16.14^{\circ}$ & 11.09 \\
\hline Saponification value & 199.0 & 197.5 & 197.3 \\
\hline Ester value & 187.39 & 181.36 & 186.21 \\
\hline Iodine value & 47.96 & 46.39 & 44.08 \\
\hline Acetyl value & 9.36 & 9.25 & 10.58 \\
\hline Hehner value & 93.51 & 93.05 & 94.16 \\
\hline Reichert-Meissl value & 1.54 & 1.56 & 1.53 \\
\hline Vitamin A & - & - & - \\
\hline
\end{tabular}

3. Nutritive Value

As far as the experiments performed, the proteins obtained from canned meats of different ages of storage havc nearly the same composition and similar nutritive value as already dcscribed ${ }^{5}$. In the present feeding experiments, we compared the nutritive value of meat-powders obtained by simply drying the total contents of cans. In every case albino rats of the same litter and of the same sex were fed with the foods containing 7 per cent of muscle proteins in the form of meat-powder.

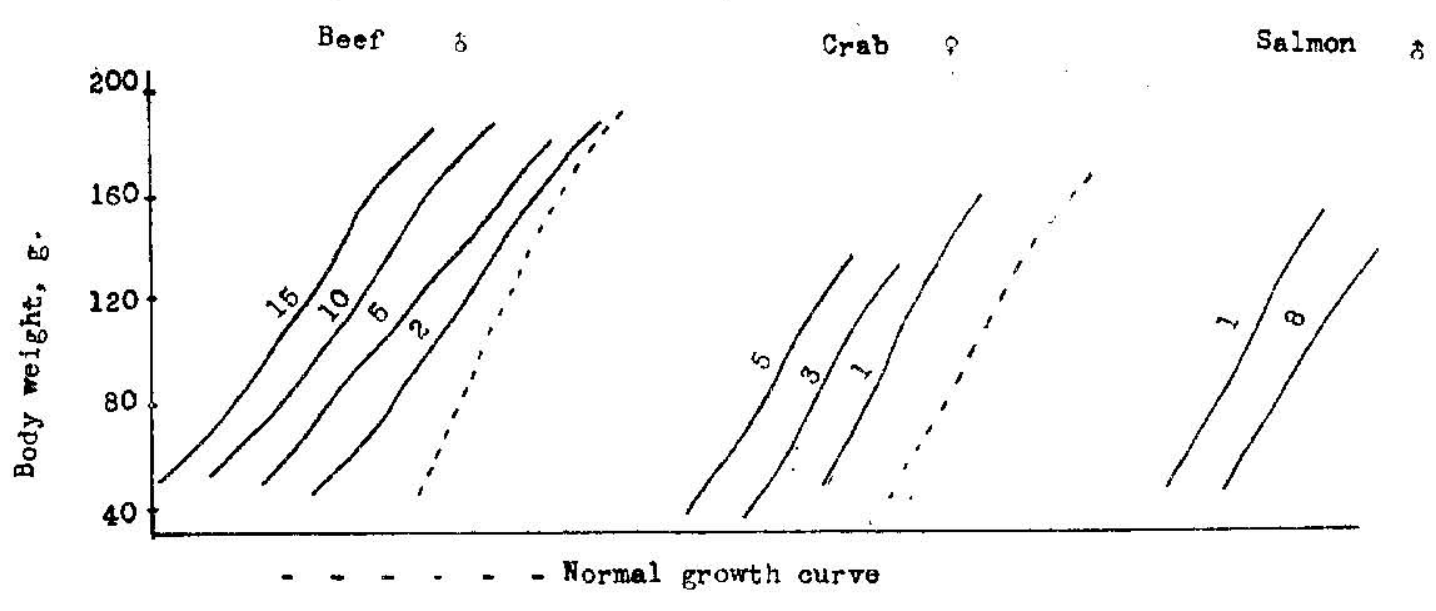


Table 6

\begin{tabular}{|c|c|c|c|c|c|c|c|c|c|c|}
\hline \multirow{2}{*}{\multicolumn{2}{|c|}{ Age of cans }} & \multicolumn{4}{|c|}{ Canned beef } & \multicolumn{3}{|c|}{ Canned crab } & \multicolumn{2}{|c|}{ Canned salmon } \\
\hline & & 15 & 10 & 5 & 2 & 5 & 3 & 1 & 8 & 1 \\
\hline \multicolumn{2}{|c|}{ Sex of rats } & $\hat{0}$ & 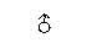 & 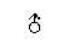 & 8 & ? & $q$ & q & s & 8 \\
\hline \multirow{7}{*}{ 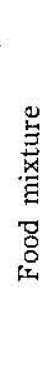 } & Meat powder, g. & 11.0 & 10.7 & 11.2 & 11.0 & 9.4 & 9.2 & 9.0 & 9.8 & 9.7 \\
\hline & Starch, g. & 64.0 & 64.3 & 63.8 & 64.0 & 65.6 & 65.8 & 66.0 & 65.2 & 65.3 \\
\hline & Cane sugar, g. & 5.0 & 5.0 & 5.0 & 5.0 & 5.0 & 5.0 & 5.0 & 5.0 & 5.0 \\
\hline & Agar-agar, g: & 1.0 & 1.0 & 1.0 & 10 & 10 & 1,0 & 10 & 10 & 10 \\
\hline & McCollum saits, $g$. & 4.0 & 4.0 & 4.0 & 4.0 & 4.0 & 4.0 & 4.0 & 4.0 & 4.0 \\
\hline & Butter, g. & 15.0 & 15.0 & 15.0 & 15.0 & 15.0 & 15.0 & 15.0 & 15.0 & 15.0 \\
\hline & Orizanin, c.c. & 4.0 & 4.0 & 4.0 & 4.0 & 4.0 & 4.0 & 4.0 & 4.0 & 4.0 \\
\hline \multicolumn{2}{|c|}{ Initial body weight, g. } & 50 & 50 & 46 & 42 & 36 & 32 & 46 & 4.4 & 46 \\
\hline \multicolumn{2}{|c|}{ Finale } & 185 & 188 & 180 & 186 & 135 & 132 & 160 & 136 & 154 \\
\hline \multirow{2}{*}{\multicolumn{2}{|c|}{$\begin{array}{l}\text { Increased ," ", } \\
\text { Increase per day, g. }\end{array}$}} & 135 & 138 & 134 & 144 & 99 & 100 & 126 & 92 & 208 \\
\hline & & 1.2 & 1.2 & 1.2 & $1.3 !$ & 1.7 & 1.7 & 2.1 & 1.5 & 1.8 \\
\hline \multicolumn{2}{|c|}{ Period of experiment } & \multicolumn{4}{|c|}{4 months } & \multicolumn{3}{|c|}{2 months } & \multicolumn{2}{|c|}{2 months } \\
\hline
\end{tabular}

According to the experimental results, in spite of the great difference of ages of storage, the meat-powders from the same kind of cans differed only slightly in nutritive. All albino rats fed with the foods containing 7 per cent of protein in the form of meat-powders showed a rate of growth a little lower than normal.

The above mentioned results were obtained in the case of experiments with the cans of superior quality, whereas in the case of materials of inferior quality the nutritive value of aged cans was much lower than that of new ones. This discrepancy may be ascribed to the difference both in the contents of the cans and in the can-materials.

To examine the injurious action of iron and tin, which form the can materials, and which came into the meat-powder by dissolving, two or three times as much iron or tin as present in ordinary meat-powders was mixed into the basal food in the form of their chlorides. The basal food contained 22 per cent of casein, 53 of starch, 5 of cane sugar, 4 of McCollum salt, 15 of butter, 
1 of agar-agar and 4 c.c. of oryzanin. With these foods male albino rats of the same litter were fed for two months.

The results are shown in the following graph. From this we see that the injurious action of an excess of iron is greater than that of tin.

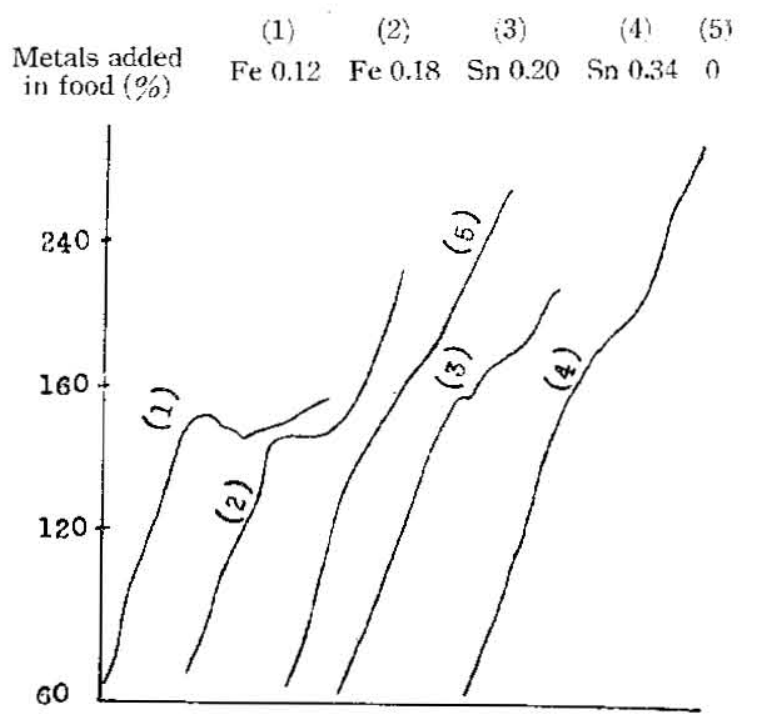

\section{Chapter V}

\section{SUMMARY}

\section{Chemical Changes of Muscle Proteins in Canning}

(1) The muscle proteins of some hens, various fishes and certain animals were prepared as samples for the purpose of studying what changes take place in the muscle proteins at the time of canning meats under pressure and heating. The materials were sealed in glass-tubes and heated at $130-140^{\circ} \mathrm{C}$ for one hour, and changes of materials were studied.

(2) The hydrogen ion concentration of all of the proteins showed a tendency to approach toward the neutral point.

(3) About 20 per cent of the protein nitrogen was trans. formed by heating to peptone, peptide, and amino acid nitrogens. 
The formation of soluble nitrogen compounds, such as these, is considered to cause a speedy putrefaction of contents of an opened can.

(4) As the results of elementary analyses of carbon, hy. drogen, nitrogen, sulphur and phosphorus, it was found that the quantities of nitrogen and sulphur contained in the proteins generally decreased by heating, and the changes were more marked the higher the values of $\mathrm{pH}$. There was no appreciable change in phosphorus when the solution was neutral, but its amount decreased when solution was acidic or alkaline, and hence the percentage of carbon increased.

(5) The quantities of $\mathrm{NH}_{3}$ and $\mathrm{H}_{2} \mathrm{~S}$ generated by heating were greater in proportion to the values of $\mathrm{pH}$ of the solutions. This results explains the fact that, when the tin of cans are bad and the $\mathrm{pH}$ of the contents is high, the contents of the can deteriorate more readily and the colour changes to black.

(6) As the results of the analyses of the proteins by the Van SYr.ke method, the decrease of the total nitrogen, ammonia nitrogen and cystine nitrogen and the incrcase of melanine nitrogen were detected especially when the $\mathrm{pH}$ value increased. The quantitities of cystine, arginine, histidine and lysine contained in the materials showed a tendency of decrease in all three cases and the same tendencies were very remarkable on cystine at the higher value of $\mathrm{pH}$ and on lysine at the lower.

(7) Tryptophane by the May-Rose method and the tyrosine by the Folin-Denies method were quantitatively analyzed, and the decrease of these substances by heating were very insignificant.

(8) The test for proline was made by the Fisher-Bechner method, but no decomposition by heating was observed.

(9) Cysteine and cystine were analyzed quantitatively by the OKUDA-KATAI method, and it was found that a part of any one of these acids always changed to the other acid by heating. But the sum of the two always decreased, and the decomposition of both of these acids was remarkable at the higher value of $\mathrm{pH}$, and the decomposition of cysteine was greater than that of cystine.

(10) A part of the protein-sulphur changed by heating to hydrogen sulphide, other sulphides, sulphuric acid and soluble 
organic sulphur, and the quantities of these substances generated were greater at the higher $\mathrm{pH}$ of the solutions, as in the case of the decompositions of cysteine and cystine.

\section{On the Contents of Gases and Metals in Storaged Cans}

The experiments were chiefly carried out with canned beef of different ages of storage, from 1 to 15 years, were as follows:

1) Among gases contained in cans examined, the quantity of nitrogen was the largest in the majority of the cans, but in some old cans the amount of hydrogen was frequently more than that of nitrogen.

2) The proportion of oxygen as compared to that of nitrogen was much smaller than it is in the air.

3) The content of carbon dioxide in cans was larger than that in the air, but it did not increase appreciably during the storage of the cans.

4) Free ammonia and hydrogen sulphide showed only traces.

5) The concentration of hydrogen ion of the canned meats showed almost no change in storage.

6) The contents of iron and tin in both canned beef and fish were nearly proportional to that of hydrogen in the cans which was produced by corrosion of ${ }^{-}$can-matcrials. But in the case of crab meat packed in the cans which are covered inside with lacquer, almost no increase of the contents of iron, tin and hydrogen was observed.

7) Unusual increase of hydrogen gas in some very longstored beef-cans sometimes gave rise to the so called "blown" cans, in which the ends become convex, and are apparently analogous to the spoiled cans dilated by the pressure of carbon dioxide produced by the action of bacteria upon the contents.

\section{Carbon Dioxide and Hydrogen Gasses Produced at Canning and in Storage}

In the present case, instead of commercial cans, sealed glass tubes containing a certain meat, tin and iron powders, and solutions of different hydrogen ion concentration were used. 
1) The production of carbon dioxide during canning increased a little more, as a rule, in the presence of iron than in the presence of tin alone. And also the longer the time of heating the more was the increase.

2) The production of carbon dioxide during storage, gradually increased in the presence of tin alone, but decreased in the presence of iron. The decrease seems to be due to the fact that carbon dioxide produced by gradual oxidation acts on iron to make iron carbonate and hydrogen.

3) The production of carbon dioxide seems to have some relation with the hydrogen ion concentration of meat-juice and the kind of meats, but the relation with the freshness of the meat is not definite.

4) The production of hydrogen is chiefly due to the presence of iron but only slightly to that of tin. In the presence of iron, the production had an intimate relation with the hydrogen ion concentration of meat-juice, the strongcr being the concentration the more the production. The production increased proportionally to the length of time of heating in canning, and to the period of storage of cans.

5) The kind and freshness of meats have more or less influence upon the production of hydrogen from can-material.

6) The quantity of carbon dioxide produced was generally very small as compared to that of hydrogen.

\section{Protein, Fat and Nutritive Value of Storaged Canned Meats}

The present investigation deals with the chemical changes of the proteins and fats, and also the nutritive value of meats in cans which have endured long storage. The results of the experiments carried out with canned meats of different ages of storage were as follows :-

1) The proteins obtained from fresh and canned beef aged from 2 to 15 years contained nearly equal amounts of nitrogen but differed greatly in amounts of ashes. The ash-content was the more the older the cans. 
2) The results of analyses of the proteins by the Van SLYKE method showed no remarkable difference each other. The analogy of the chemical composition of those proteins indicates the similarity of the nutritive value of them. This result agrees with that of feeding experiments performed by us long years ago.

3) Acid value, saponification value, ester value, iodine value, acetyl value, Hehner value, and Reichert-Meissl value were examined in the fats obtained from fresh and canned beef of different ages of storage, but no definite conclusions were obtained, exceps that the longer the time of storage the higher was the acid value.

4) Carr-Price test for vitamin A was negative in all of the fats exânined.

5) The nutritive value of the meat powders obtained from canned beef from 2 to 15 years old, and from canned crab from 1 to 5 years old showed only slight differences, when feeding experiments were performed with albino rats.

6) When the great excess of iron and tin in the form of their chlorides was administrated to the rats, the injurious action of iron was greater than that of tin.

In conclusion the authors wish to express their thanks to Messrs. U. Endo, S. Nagatake and S. Sigematu for their analytical works and also to "Hattori-Hokokwai" for a research grant which has defrayed a part of the cost of this investigation. 